\title{
RENATA KNYSPEL-KOPEĆ*
}

\section{"Co wypada, a co nie" \\ Edukacyjna rola „Mojej Przyjaciółki” w zakresie nienagannego sposobu bycia kobiety}

Zapotrzebowanie kobiet na poradnictwo z zakresu savoir vivre zaspokajała w latach trzydziestych XX stulecia m.in. „Moja Przyjaciółka”. Edukacyjny charakter pisma wyrażał się dążeniem redakcji do rozpowszechniania właściwego stylu bycia kobiety zarówno w środowisku domowym, jak i towarzyskim. Czasopismo kobiece „Moja Przyjaciółka” założone zostało w 1934 r. w Żninie (Wielkopolska) przez Alfreda Krzyckiego i początkowo ukazywało się pod redakcją wydawcy, następnie jego żony Anny. Zeszyty składające się z szesnastu kolumn średniego formatu drukowano najpierw na papierze niskiej jakości, dlatego też zamieszczane w piśmie ilustracje charakteryzował wówczas słaby poziom techniczny. Dopiero latem 1936 r. rozpoczęto druk na lepszym papierze i zastosowano kolorową okładkę. Zmiany te pociągnęły za sobą zwiększenie kosztów wydawniczych, o czym redakcja poinformowała przy okazji ogłoszenia konkursu „gwiazdkowego”, mającego zachęcić stałe czytelniczki do zjednywania następnych prenumeratorek. „[...] Koszty wydawania „Mojej Przyjaciółki” - pisano - bardzo wzrosły od czasu jej założenia - gdyż powiększyła się znacznie objętość pisma, doszła barwna okładka, lepszy papier i inne ulepszenia - natomiast wysokość prenumeraty wciąż jest ta sama"'.

Układ pisma obejmował dwie wyraźnie wyodrębnione części. Pierwsza z nich o objętości 6-7 kolumn prezentowała charakter ilustrowanego magazynu poświęconego sprawom kobiet. Podawano tutaj informacje, komentarze oraz artykuły o życiu i działalności organizacji kobiecych na świecie, przybliżano sylwetki znanych opinii publicznej reprezentantek świata polityki, literatury i sztuki. Czytelniczki „Mojej Przyjaciółki” mogły w tej części śledzić losy bohaterów powieści i nowel, których fragmenty drukowano w kolejnych numerach pisma. Drugą część magazynu przeznaczono m.in. na problematykę praktycznego poradnictwa, do-

* Dr.

${ }^{1}$ Gwiazdkowy konkurs „Mojej Przyjaciółki”, „Moja Przyjaciółka” [dalej: MP] 1936, R. III, nr 23, s. 510 . 
tyczącego dobrych manier, które prezentowano w rubryce opatrzonej tytułem „Co wypada - a co nie" oraz sprawom gospodarstwa domowego, mody, higieny i wychowania dzieci.

Czytelniczki „Mojej Przyjaciółki” należały do różnych warstw społecznych, były to zarówno "gospodynie domowe, jak i kobiety, które prowadziły ogródki działkowe czy też gospodarstwa rolne"'. Znajdowały one tutaj szereg cennych rad związanych z tematyką nienagannego sposobu prowadzenia domu i prezentowania się w warunkach domowych, ale i podczas wizyt towarzyskich poza domem.

Pierwszy numer dwutygodnika ilustrowanego dla kobiet ukazał się 10 stycznia 1934 r. i, jak zapewniała redakcja, „wychodzi [on] w świat jak promień słoneczny, by ogrzać swem ciepłem tych wszystkich, którzy nie są zapatrzonymi we własne siły tylko - egoistami, ale doceniają wartość współżycia z bliźnimi”3. Formuła pisma zachęcała czytelniczki do nawiązywania między sobą dialogu na łamach periodyku, który już od premierowego numeru rozpoczął publikowanie redagowanej właśnie przez swoje odbiorczynie kolumny poświęconej wszelkim sprawom kobiet. Wydawca, przyjmując za główny cel pisma staranie się „o nawiązanie serdecznego, silnego i trwałego węzła przyjaźni między kobietami wszystkich warstw i wszystkich zapatrywań"4, prosił o nadsyłanie pytań, życzeń, spostrzeżeń, wskazówek i rad. Teksty do działu „My kobiety między sobą" powstawały przy współpracy działaczki społecznej skrywającej się pod pseudonimem Zofja. Zdaniem Feliksa Fikusa, który w niewielkim artykule zamieszczonym w „Kwartalniku Historii Prasy Polskiej”, wypowiedział się na temat periodyku, wspomnianą redaktorką była Zofia Zawadzka. Znana nie tylko w Polsce, ale i za granicą ze „swego zrozumienia dla wszystkich trosk i kłopotów ludzkich [...]"5, przejawiającego się w prowadzonym przez nią dziale w tygodniku „Moje Powieści”.

Pierwsze wrażenia z lektury „Mojej Przyjaciółki” autorstwa Marii Zabielskiej z Poznania ukazały się na łamach pisma wraz z jego drugim numerem. Czytelniczka wyraziła nieskrywane zadowolenie $z$ pojawienia się na rynku wydawniczym pisma „wszechstronnego co do treści a przytem niezmiernie taniego [...]”. Powszechnym zainteresowaniem cieszył się zwłaszcza kącik „My kobiety między sobą", gdzie panie dzieliły się swoimi obawami, troskami i radami na tematy dotyczące zarówno urody, zdrowia, jak i gospodarstwa domowego. Zjawisko publikowania tzw. listów do redakcji, pisanych przez samych pracowników czasopism było dość powszechne. Nie znaleziono jednak w literaturze przedmiotu żadnych wzmianek dotyczących ewentualnego preparowania niniejszego działu przez redaktorów pisma. Natomiast w pracy Joanny Grabowskiej, która bez cienia wątpliwości przekonuje, iż: „Czytelniczki zwracały się do redakcji z wieloma zapytaniami, jak do swojej najlepszej przyjaciółki, która z pewnością nie zawiedzie,

2 J. Grabow ska, Moja Przyjaciółka. Ilustrowany dwutygodnik kobiecy 1934-1939, Żnin 1997, s. 39.

${ }^{3}$ My - kobiety - między sobą. Z serca do serca - Między nami..., MP 1934, R. I, nr 1, s. 2 [Wszystkie cytaty w artykule zachowują oryginalną pisownię.].

${ }^{4}$ Tamże.

${ }^{5}$ F. F i ku s, Wielkie wydawnictwo prasowe w małym mieście. Dwie „Przyjaciółki”, „Kwartalnik Historii Prasy Polskiej" 1979, R. XVIII, nr 1, s. 83.

${ }^{6}$ My kobiety - między sobą, MP 1934, R. I, nr 2, s. 11. 
a wesprze i pomoże. Zaprezentowana korespondencja potwierdza, że czytelniczki, w pewnym stopniu współredagowały czasopismo, jak również wzajemnie udzielały sobie porad w zakresie wyglądu, zdrowia i zachowania"7.

Stałym punktem dwutygodnika był przede wszystkim interesujący nas tutaj dział "Co wypada - a co nie”, w którym prezentowano szereg porad z zakresu bon ton. Z lektury tej rubryki czytelniczki mogły dowiedzieć się, na przykład, o formach właściwego zachowania się w towarzystwie, na przyjęciach i podczas rozrywek kulturalnych czy uroczystych posiłków w domu i poza nim. „Moja Przyjaciółka” podawała cenne uwagi zwłaszcza na temat kultury spożywania posiłków i organizowania przyjęć. Ten stały temat poruszany był w piśmie $z$ uwagi na fakt, iż redakcja dostrzegała zdecydowany brak dobrych manier w tej kwestii, dotyczący wielu ówczesnych polskich domów. Czasopismo podkreślało, iż należy przykładać znaczną wagę do schludnego ubioru, w jakim powinno siadać się do stołu, nie należy podczas posiłków czytywać gazet ani poruszać tematów drażliwych ${ }^{8}$.

Napływające do wydawcy wyrazy sympatii i głosy rosnącego zapotrzebowania na publicystykę „Mojej Przyjaciółki” sprawiły, iż wydano na 1936 r. „Almanach” tego pisma. Redaktor informował, iż starano się przedstawić w niniejszym dodatku treści różnorodne i nacechowane aktualną wymową. „Założeniem naszem było, pisał A. Ksycki - by „Almanach” stanowił niejako uzupełnienie „Mojej Przyjaciółki”, by tak samo, jak ona służył niezawodną radą i pomocą nawet najdoświadczeńszym paniom domu”. „Almanach" uwzględniał ważne ówczesne sprawy kobiecej egzystencji toczącej się zarówno na niwie rodzinnej, jak i towarzyskiej, udzielając czytelniczkom praktycznych wskazówek. Niezwykle ważne dla każdej kobiety jest bowiem: „Życie towarzyskie - [...] życie taktu, etykiety, dobrego tonu, elegancyi, grzeczności, układności itp. przymiotów w stosunkach ogólno ludzkich; [... $]^{10}$.

Panie dowiadywały się z lektury pisma m.in. o tym, że: „Zasadnicze nakrycia stołu codziennego, a stołu wystawnego różnią się tylko na bardzo niewielu punktach. Skromniejsza zastawa, brak kosztownych owoców i bogatej dekoracji kwietnej, pozbawiają go z konieczności świetnego wyglądu, jakim pyszni się w dnie licznych przyjęć. Jednak nieskazitelnie czysta i świeża bielizna, zręcznie ułożone serwetki (mogą być nawet papierowe ustawione w specjalnej podstawce), noże, widelce i łyżki prawidłowo i starannie rozmieszczone, lśniące czystością szklanki i karafki, sól miałka w maleńkich solniczkach, napełnionych po brzegi, chleb cieniutko pokrojony i ułożony na podstawce przykrytej ładnie wyhaftowana serwetką - to wszystko stwarza cechy komfortu i przyczynia się do miłego nastroju. [...]. Po skończonym podstawowym posiłku, [...]. Dopiero po uprzątnięciu stołu jadalnego i przywróceniu mu estetycznego wyglądu, podaje się deser, - a gazety, książki, robótki itp. wolno rozłożyć dopiero wtedy, gdy obrus ze stołu zostanie zdjęty"11.

Na wspomniany temat odnośnie do nakrywania do stołu i łączące się z nim

7 J. G r a b ow s k a, Moja Przyjaciółka, s. 38.

${ }^{8}$ K. Ło z ow sk a-M a r cin k ow ska, Sprawy niewieście. Problematyka czasopism kobiecych Drugiej Rzeczypospolitej, Poznań 2010, s. 179.

9 „Almanach”, MP 1936, s. 3.

${ }^{10}$ M. Rościszowski, Księga obyczajów towarzyskich, Przedmowa, Lwów-Złoczów, b.r.w., s. V.

${ }^{11}$ M. S a r y u s z-S t o k o w s k a, Dbajmy o dobry nastrój przy stole, tamże, s. 39, 40. 
sprawy dotyczące przyjmowania gości, wydawania przyjęć i tzw. herbatek wieczornych, „Moja Przyjaciółka” podawała wiele cennych wskazówek. Pani domu, która postanowi zorganizować przyjęcie, na które w odpowiedni sposób zaprosi gości, powinna przede wszystkim uporządkować i udekorować mieszkanie. Forma zaproszenia jest zależna od stopnia uroczystości danej imprezy, o niezbyt oficjalnym spotkaniu można gości zawiadomić ustnie, przy czym te oficjalne wymagają zaproszenia za pomocą korespondencji pisemnej. „Na wykwintne przyjęcia podaje się [...] (menu) na ozdobnych kartkach, które nabyć można w handlach papieru i karty te stawia się na stole przed każdym z gości, opierając je o kieliszki”12. „Jeżeli chodzi o eleganckie nakrycie stołu na przyjęcie, to potrzeba tu dużo delikatnego smaku i gustu. Najpierwszym warunkiem jest obrus, który, musi być śnieżnej białości i dość długi i szeroki, [...] Natomiast pani domu po wydaniu wszelkich dyspozycji służbie, „sama powinna siedzieć przy stole wesoła i uśmiechnięta. [...] Wszelkie jej zbytnie wstawanie od stołu i zajmowanie się podawaniem, nieprzyjemnie działa na gości”13. Ponadto powinna ona jeść posiłek, dopóki goście zajęci są jedzeniem, a w razie konieczności dyskretnie udawać, iż także pochłonięta jest jedzeniem ${ }^{14}$.

W dobrym tonie jest również to, aby gospodyni przyjęcia ubrana była w sposób podkreślający uroczysty nastrój, jednakże nie powinna być zbyt strojna w stosunku do wizytujących jej dom pań ${ }^{15}$. Dalej w artykule poświęconym poradnictwu z zakresu dobrego smaku, następowało wyliczanie, jakie i w którym miejscu na stole powinny zostać ustawione naczynia. W jednym z wydań „Mojej Przyjaciółki” pisano, iż należy pamiętać o tym, iż nie jest ważne, co jemy, ale jak to jemy. W celu dokładnego zobrazowania niniejszej zasady zamieszczono ilustracje w charakterze instruktażu. Przypomniano, iż eleganckie siedzenie przy stole zabrania trzymania na nim łokci, zaś spożywanie zupy przechylając talerz jest rażącym uchybieniem przeciwko etykiecie towarzyskiej ${ }^{16}$.

Tymczasem, aby uniknąć towarzyskiego potknięcia, którego ceną może być osłabienie kontaktów, uświadamiano czytelniczki, iż powinny przyjrzeć się wnikliwie manierom swoim, jak i reszty domowników. Akcentowano, iż ogłada w towarzystwie pozwala na komfortowe i pewne samopoczucie, nawet podczas przyjęć najbardziej wytwornych ${ }^{17}$.

Przekonywano natomiast, że zorganizowanie herbaty popołudniowej jest najłatwiejszą formą przyjęcia towarzyskiego, podczas którego nienaganna pani domu z całą starannością dba o to, aby nikt z gości nie został pominięty przy nalewaniu do filiżanek herbaty lub kawy ${ }^{18}$. Należy pamiętać o podaniu gościom kruchych ciasteczek bądź czekoladek wraz z osobnym dla każdego talerzykiem ${ }^{19}$. Częściej

12 „Co wypada - a co nie...”, Przyjmowanie gości, MP 1934, R. I, nr 7, s. 16.

13 "Co wypada - a co nie...", O przyjęciach (Na specjalne życzenie jednej z Czytelniczek), MP 1935, R. II, nr 11, s. 174.

14 „Co wypada - a co nie...", Jak należy podawać do stołu, MP 1935, R. II, nr 17, s 267.

15 „Co wypada - a co nie...", MP 1935, R. II, nr 21, s. 334.

16 „Co wypada - a co nie...", Jak używać nakryć przy stole, MP 1936, R. III, nr 19, s. 399.

17 K. Ł o z o w s k a-M a r c in k o w s k a, Sprawy niewieście, s. 180.

18 "Co wypada - a co nie...”, Herbatka popołudniowa, MP 1935, R. II, nr 19, s. 299.

19 "Co wypada - a co nie...", Herbatka popołudniowa, MP 1936, R. III, nr 14, s. 288. 
w periodyku przeczytać można było o przygotowywaniu przyjęć ze skromnym menu niż o tych wystawnych z wyszukanymi potrawami. Ze względu na trwający w Polsce kryzys ekonomiczny lat trzydziestych XX stulecia, który wywierał także duży wpływ na prasowy rynek wydawniczy, najmodniejsze były popołudniowe spotkania domowe ${ }^{20}$. Zarówno właściciele gazet, jak i czytelnicy borykali się z trudnościami natury finansowej. Kolegium redakcyjne koncernu Krzyckich świetnie zdawało sobie sprawę z sytuacji gospodarczej panującej w kraju, która niestety nie sprzyjała sprzedaży. Dlatego też już w lutym 1935 r. redakcja pisma zabiegała o nowe czytelniczki i zachęcała stałe do kupna „Mojej Przyjaciółki”, zapowiadając dołączanie do wybranych egzemplarzy arkuszy wzorów do „robótek ręcznych”21.

Ponadto, pismo swoją treścią i propozycjami skierowanymi do kobiet w kwestiach edukowania w zakresie dobrego smaku przystawało do możliwości ekonomicznych swoich czytelniczek. Najczęściej porady wskazywały na szereg możliwości osiągnięcia zamierzonego skutku za pomocą niezbyt wysokich kosztów finansowych. Kobieta w sposób skromny i niedrogi mogła, zdaniem „Mojej Przyjaciółki”, dbać zarówno o dom, jego mieszkańców, jak i samą siebie. Zawsze powinna jednak pamiętać o kulturalnym i eleganckim sposobie bycia wśród domowników i gości, we własnym mieszkaniu i poza nim, w restauracji i podróży. Każde spotkanie towarzyskie wymaga bowiem określonego kulturalnego zachowania.

Czasopismo "Moja Przyjaciółka” pełniło w tej kwestii rolę edukacyjną, zamieszczając na swoich łamach porady będące często odpowiedzią na listy czytelniczek pełne wątpliwości i pytań odnośnie do życia towarzyskiego. Na jeden z nich redakcja odpowiedziała, informując zainteresowaną czytelniczkę, iż przy powitaniu lub pożegnaniu się ze starszą osobą można ją pocałować w dłoń, jednakże zwyczaj ten nie stanowi konieczności22. Przy innej okazji pismo przypominało kobietom, iż po przyjściu na miejsce spotkania zobowiązane są przywitać się najpierw z panią, która jest gospodynią imprezy, następnie z innymi znanymi już sobie kobietami. Natomiast witając się z mężczyznami, kobieta, jak zapewniano, nie ma obowiązku unosić się z miejsca, na którym siedzi. Nie dotyczy to jednak sytuacji, gdy wita się ona ze starszym od siebie lub pełniącym wysoką funkcję społeczną mężczyzną ${ }^{23}$. Inną formą powitania jest ukłon, który powinien wyrażać szacunek i sympatię wobec osoby, do której jest kierowany. „Kobieta kłania się pochyleniem głowy. Nie powinno to być sztywne kiwnięcie, zupełnie pozbawione wdzięku i uprzejmości. Głowa przez sekundę pozostaje pochyloną i podnosi się wolno. Im głębsze pochylenie i dłuższe podnoszenie się, tym ukłon jest uprzejmiejszy. Ani ramiona, ani łopatki nie biorą w nim udziału, pracuje tylko głowa i szyja.

Pragnąc pozdrowić osobę mało znajomą i okazać jej szacunek, dama schyla głowę nisko, zachowując zupełny spokój na twarzy. Uśmiech przy tym ukłonie

${ }^{20}$ K. Ł o z o w s k a-M a r c in k o w s k a, Sprawy niewieście, s. 182-183.

${ }^{21}$ MP1935, R. II, nr 3, s. 1.

${ }^{22}$ Co wypada?, MP 1936, R. III, nr 22, s. 484.

${ }^{23}$ "Co wypada - a co nie...", Formy witania się. (Na życzenie jednej z Czytelniczek), MP1936, R. III, nr 4, s. 55. 
jest dowodem bliższego stosunku. Kilkakrotne kiwanie głową, mruganie oczami i robienie min świadczy o niezbyt wykwintnem wychowaniu damy"24.

Spotkaniom towarzyskim zarówno tym, które mają miejsce w domach prywatnych, jak i lokalach publicznych zawsze towarzyszy rozmowa, której umiejętność prowadzenia ma niezwykle istotne znaczenie dla przebiegu całego spotkania. „Niezależnie od treści i poziomu prowadzonej rozmowy należy zawsze pamiętać, by utrzymana była w tonie kulturalnym, a więc nie unosić się przy dyspucie, nie zaprzeczać ostro swemu rozmówcy, a zwłaszcza nie zadawać mu kłamu, nie poruszać w nieodpowiedni, lekki lub ironiczny sposób tematów, które głębiej go dotykają i mogą sprawić mu przykrość.

Umiejętność uszanowania cudzych przeszkód i wysłuchania wszystkich zdań, chociażby się skrajnie różniły od naszego, jest dowodem kultury i ogłady towarzyskiej"25. Ponadto, rozmowa toczona w towarzystwie powinna być pozbawiona tematyki osobistej i intymnejej ${ }^{26}$. Natomiast należy prowadzić ją się w sposób dyskretny, taktowny, nacechowany skromnością i pozbawiony wszelkiego zadufania w stosunku do siebie ${ }^{27}$. Kulturalna i dobrze wychowana kobieta, odwiedzając na przykład kino czy wystawę sztuki, nie prowadzi głośnej rozmowy, unika gwałtownej krytyki i komentarzy, nie zwraca na siebie ogólnej uwagi pozostałych osób ${ }^{28}$. „Rozum i wdzięk czynią kobiety miłemi i przyjemnemi w towarzystwie, pisał M. Rościszowski, ale największy urok w kobiecie stanowi jej skromność, unikająca poklasków zewnętrznych i zwiększająca tem samem cenę jej piękności.

Niech kobieta będzie jaknajurodziwszą, nigdy nie powinna się tem szczycić; powinna być skromną, [...].

Bądźcie zawsze uprzejme, uprzejmość bowiem jest potężną bronią w rękach kobiety.

Nie zapominajcie ani na chwilę, że największa wyższość kobiety polega na tem, ażeby była skromną wszędzie i zawsze i ażeby była grzeczną nawet względem tych ludzi, których mogłaby nie szanować, t. j. takich, którzy przez swoje postępki nie zasługują na szacunek.

Skromność sama przez się jest tak pięknym przymiotem, że przyznaje się jej daleko więcej wartości, aniżeli pięknej twarzy i monarszej postaci; ale skromność wykazuje się nietylko w samej powierzchowności, lecz także w: ubraniu, w ruchach, $[\ldots]$.

Uprzejmość, której gruntu szukać należy w dobroci serca, jest to uprzedzająca delikatność postępowania względem wszystkich i każdego; jest to wrodzona dążność do szanowania i poważania tych wszystkich, którzy mają do tego prawo,

${ }^{24}$ "Co wypada - a co nie...", MP 1935, R. II, nr 3, s. 43.

25 "Co wypada, a co nie...”, Rozmowa Towarzyska, MP 1934, R. I, nr 14, s. 2, 12; „Co wypada, a co nie...", Jak prowadzić towarzyską rozmowę?, MP 1934, R. I, nr 18, s. 8.

${ }^{26}$ Co wypada, a co nie? Uczymy się rozmawiać, MP 1938, R. V, nr 3, s. 56.

27 „Co wypada, a co nie...”, Skromność, MP 1934, R. I, nr 11, s. 5; „Co wypada, a co nie...”, Prostota i naturalność, MP 1934, R. I, nr 12, s. 6; „Co wypada, a co nie...”, O ważnych zaletach towarzyskich, MP 1935, R. II, nr 6, s. 94.

28 „Co wypada, a co nie...”, Muzeum, wystawa, MP 1935, R. II, nr 4, s. 58. 
zależnie od pozycyi, zajmowanej w towarzystwie lub od zalet osobistych"29.

Innym miejscem publicznym jest środek lokomocji, w którym znajdującą się kobietę będącą w podróży także tutaj obowiązują określone normy dobrego wychowania. Przestrzeganie ich nie tylko może ułatwić, ale i uprzyjemnić podróżowanie. Otóż nienaganna w swym sposobie bycia pani, zwłaszcza niezamężna i nieposiadająca towarzystwa powinna zająć przedział przeznaczony dla kobiet. Bowiem „[...] winna [ona] w takim wypadku być bardzo ostrożna, aby jej nikt nie posądził o szukanie przygód"30. Należy również pamiętać o tym, aby bagaż podróżny nie był kłopotliwie obfity, gdyż „Człowiek prawdziwie kulturalny i przyzwyczajony do podróżowania potrafi się obyć minimalną ilością ręcznych pakunków"31.

Z lektury czasopisma „Moja Przyjaciółka” wynika, iż w latach trzydziestych XX stulecia kobiety zarówno te, które pracowały zawodowo (a było ich niemało), jak i te, których domeną był tylko dom, potrzebowały wiedzy na temat poprawnego funkcjonowania w różnych sytuacjach. „Zadania i kompetencje kobiety zarządzającej domem były rozległe. Nie wystarczyło być wzorową gospodynią, na tę funkcję składało się też bycie dobrą żoną i matką"32. Poza tym oczekiwano od kobiet, że będą prezentowały się w sposób nienaganny, jeśli chodzi o ogładę towarzyską, a także ich wygląd zewnętrzny. Wychodząc naprzeciw oczekiwaniom swoich czytelniczek, pismo zamieszczało na swoich łamach liczne porady z zakresu dobrych manier, stając się przez to cennym źródłem edukacyjnym dla kobiet wspomnianego okresu. W związku z wymogami i codziennymi obowiązkami, kobiety najczęściej musiały wykazywać się licznymi umiejętnościami i znajomością wielu dziedzin wiedzy. Realizować się zaś powinny poprzez troskliwe opiekowanie się dziećmi i mężem, dbanie o dietę i higienę domowników, wystrój mieszkania oraz racjonalne dysponowanie budżetem domowym. Przy tym miały być zadbane i modnie ubrane, zainteresowane własnym rozwojem intelektualnym i uprawiające sporty. Również w tym temacie „Moja Przyjaciółka” spełniała oczekiwania kobiet. Każdy egzemplarz pisma zawierał nowinki ze świata mody, m.in. rubrykę „Co lansuje Paryż”. Dodatkowo tuż przed wybuchem drugiej wojny światowej wydawnictwo Krzyckich opublikowało pierwszy polski miesięcznik mody. Ten oryginalny żurnal zatytułowany „Rewia Mody” opatrzono kolorowymi zdjęciami modelek oraz wykrojami najmodniejszych wówczas strojów. Ponadto zapowiedziano, iż w każdym kolejnym numerze pisma zamieszczane będą hafty i robótki oparte na regionalnych ludowych wzorach polskich. Wydawca informował szczegółowo czytelniczki o tym, że katalog mody jest jedynym polskim pismem o tej tematyce. „W Polsce - pisano - znajduje się w sprzedaży ponad 160 żurnali mód. Żaden z nich nie jest całkowicie wykonany w kraju, nawet te, które wychodzą w języku polskim! [...]

Chcąc tej przykrej sytuacji nareszcie kres położyć, wydawnictwo nasze postanowiło wydać czysto polski i chrześcijański miesięcznik [...]"33.

Redakcja „Mojej Przyjaciółki”, podobnie zresztą jak innych czasopism okre-

${ }^{29}$ M. R o ś c i s z o w s k i, Księga obyczajów..., s. 73, 82, 113.

30 "Co wypada, a co nie...", Podróż, MP 1935, R. II, nr 14, s. 219.

31 Tamże.

${ }^{32}$ K. Ł o z o w s k a-M a r c in k o w s k a, Sprawy niewieście, s. 132.

33 „Rewia Mody”, dodatek do MP 1939, s. 3. 
su międzywojennego, pochylała się nad prozaicznymi problemami dotyczącymi codziennych kwestii związanych z funkcjonowaniem kobiet w pracy zawodowej, życiu codziennym i towarzyskim. Ogromny sukces czasopisma, przejawiający się zwłaszcza w ilości publikowanych egzemplarzy, spowodowany był przede wszystkim utrzymywaniem przez redakcję niezwykle bliskiego kontaktu z czytelniczkami. „Moja Przyjaciółka” stanowiła poradnik życia codziennego, który pełen był wartościowych wskazówek, porad i sugestii, których stosowanie miało ułatwić paniom pełnienie z powodzeniem szeregu ról społecznych. Pismo pełne było życiowych porad dotyczących savoir vivre, praktycznych rozwiązań, nie brakowało w nim reportaży z odległych i egzotycznych miejsc świata, nowinek z dziedziny mody, kulinariów czy techniki.

Rozległa tematyka periodyku prezentującego m.in. poradnictwo z zakresu dobrych manier, stosowania mody oraz rozrywek sportowych i towarzyskich, służyły kobietom nie tylko praktycznie, ale i edukacyjnie. „Moja Przyjaciółka” stanowi zatem źródło bogatej wiedzy o egzystencji kobiet, ich ambicjach, zainteresowaniach oraz problemach dnia codziennego. Obraz Polki lat trzydziestych XX w. kształtujący się na tle lektury pisma, nakreślony został przez jego redakcję, ale i same czytelniczki. Publikując artykuły, zamieszczając pisane przez nie listy oraz drukując wyniki ich prac konkursowych, redakcja pisma nakreśliła wzór ówczesnej kobiety. Wyłoniła się sylwetka kobiety nowoczesnej, świadomie dążącej do eleganckiego wyglądu oraz nienagannego sposobu bycia, zainteresowanej zdobyciem wszechstronnej wiedzy niezbędnej w prowadzeniu życia rodzinnego i towarzyskiego. Przy tym kobiety niezapominającej o własnym rozwoju intelektualnym i całościowej dbałości o wygląd zewnętrzny, gdyż działania te miały zapewnić jej udane relacje z mężem i przyjaciółmi. Charakterystyczne dla omawianego okresu dziejów i warte zaznaczenia jest to, iż kobiety coraz częściej interesowały się nie tylko praktycznym poradnictwem domowym, ale także zdobywały wiedzę w wielu innych dziedzinach. Publicystyka „Mojej Przyjaciółki” z pewnością znacząco wpłynęła na wykreowany wówczas na długi czas obraz kobiety. Wizerunek Polki okresu międzywojennego jawi się zatem jako kobiety godzącej różne role społeczne, zainteresowanej żywo zarówno poradami z dziedziny gospodarstwa domowego, zagadnieniami pedagogicznymi, jak i literaturą, i światem mody. Dotyczyło to zwłaszcza kobiet wyemancypowanych i zamożniejszych, jednak coraz więcej pań sięgało po lekturę czasopism kobiecych. Tymczasem tradycyjny model rodziny, w której kobieta przede wszystkim spełnia się jako troskliwa matka i oddana żona, będąc przy tym ozdobą swego męża, wydawał się być nadal dominującym. 